\title{
Sosialisasi dan Simulasi Pemberian Bantuan Hidup Dasar Pada Nelayan Tradisional di Desa Kawa Kabupaten Seram Bagian Barat
}

\author{
La Rakhmat Wabula*1, Maritje S. J. Malisngorar² \\ 1,2Program Studi Ilmu Keperawatan, STIKes Maluku Husada \\ *e-mail: la.rakhmat.wabula.stikesmh@gmail.com ${ }^{1}$, ichemalisngorar@gmail.com ${ }^{2}$
}

Nomor Handphone Untuk keperluan koordinasi : 0852-3402-6052

\begin{abstract}
Abstrak
Maluku merupakan salah satu provinsi bahari di Indonesia yang sebagian besar masyarakatnya hidup sebagai nelayan tradisional dan tinggal di Kawasan Pesisir. Sebaran masyarakat Desa Kawa adalah hidup di daerah pesisir yang berhadapan dengan lautan dimana bermata pencaharian utama adalah nelayan. Letak Desa Kawa dengan pelayanan kesehatan (Puskesmas) dibatasi dengan transportasi darat dan lautan dengan jarak tempuh \pm 45 menit. Hal ini membuat masyarakat tidak terlalu peka dengan masalah kesehatan dan terbiasa hidup mandiri namun tidak tahu akan tndakan mandiri dalam menangani sebuah masalah kegawatdaruratan. Berdasarkan data yang diperoleh di Masyarakat Desa Kawa selama ini sering terjadi kecelakaan berupa tenggelam, sehingga masyarakat ingin tahu akan penanganan pertama pada kasus tenggelam. Hal ini didasari pada lokasi desa yang jauh dari tenaga penolong (paramedis dan medis) dan tempat pertolongan (Puskesmas), sehingga masyarakat berkeinginan kuat untuk bisa secara mandiri melakukan cara pertolongan (Bantuan Hidup Dasar) pada kasus kecelakaan yang terjadi di laut, salah satunya adalah tenggelam. Demi meningkatkan pengetahuan dan keterampilan masyarakat awam di pesisir untuk memberikan pertolongan BHD yang tepat, maka berdasarkan analisis tim pengabdian di Desa Kawa untuk diberikan solusi yaitu melakukan sosialisasi dan simulasi Bantuan Hidup Dasar (BHD) untuk masyarakat awam dengan sasaran adalah masyarakat yang berprofesi sebagai nelayan dengan metode ceramah dan simulasi tindakan. Adapun hasil kegiatan yang dicapai dari kegiatan ini terdapat peningkatan pengetahuan diketahui dari hasil post-test. Kenaikan nilai post-test sebesar $61,5 \%$ nelayan tradisional mempunyai pengetahuan baik.
\end{abstract}

Kata kunci: Bantuan Hidup Dasar, Nelayan Tradisonal, Masayrakat Awam

\begin{abstract}
Maluku is one of the maritime provinces in Indonesia where most of the people live as traditional fishermen and live in the Coastal Zone. The distribution of the people of Kawa Village is living in coastal areas facing the ocean where the main livelihood is fishermen. The location of Kawa Village with health services (Puskesmas) is limited by land and sea transportation with a distance of \pm 45 minutes. This makes people less sensitive to health problems and accustomed to living independently but do not know about independent action in dealing with an emergency problem. Based on data obtained in the Kawa Village Community, accidents often occur in the form of drowning, so people want to know about the first treatment in drowning cases. This is based on the location of the village which is far from rescue workers (paramedics and medical) and the place of assistance (Puskesmas), so that the community has a strong desire to be able to independently carry out rescue methods (Basic Life Support) in cases of accidents that occur at sea, one of which is drowned. To improve the knowledge and skills of ordinary people on the coast to provide appropriate BLS assistance, based on the analysis of the service team in Kawa Village to provide a solution, namely socializing and simulating Basic Life Support (BLS) for ordinary people, the target is people who work as fishermen with lecture method and action simulation. As for the results of the activities achieved from this activity, there is an increase in knowledge which is known from the results of the post-test. The increase in the post-test score of 61.5\% of traditional fishermen has good knowledge.
\end{abstract}

Keywords: Basic Life Support, Traditional Fisherman, Lay Community

\section{PENDAHULUAN}

Indonesia adalah negara kepulauan yang hampir 70\% wilayahnya terdiri dari laut. Kondisi geografis seperti ini sebagian besar penduduk pesisir mempunyai mata pencaharian sebagai nelayan. Nelayan tradisional tersebar di Wilayah Indonesia terutama di daerah pesisir dan 
kepulauan, tetapi sampai sekarang belum ada data yang akurat menyangkut keberadaan nelayan tradisional tersebut [1].

Salah satu komunitas nelayan tradisional ditemukan di Provinsi Maluku khususnya di Desa Kawa Kabupaten Seram Bagian Barat. Keahlian melaut diperoleh secara turun-temurun. Nelayan tradisional belum memperoleh pendidikan dan pelatihan formal terkait melaut yang baik dan benar. Aspek keselamatan dan kesehatan saat melaut dan alat yang digunakan belum terstandar [2]. Risiko cidera, penyakit dan tenggelam akibat melaut yang tidak terstandar meningkat lebih tinggi dan ketidaktahuan nelayan tradisional terhadap tindakan awal kegawatdaruratan terkhususnya tindakan pemberian bantuan hidup dasar pada korban tenggelam, sampai saat ini belum pernah dieksplorasi [3].

Berdasarkan hasil wawancara dengan Kepala Nelayan Tradisional didapatkan bahwa dalam tiga bulan terakhir pada bulan April-Juni 2021 terdapat 8 orang nelayan yang tenggelam saat melaut, diantaranya terdapat 5 orang nelayan tidak terselamatkan. Berdasarkan informasi yang didapatkan bahwa nelayan tidak mengetahui tindakan awal kegawatdaruratan yang harus dilakukan untuk menolong korban tenggelam.

Tenggelam adalah penyebab utama ketiga kematian akibat kecelakaan yang tidak disengaja di seluruh dunia dan diperkirakan global secara signifikan didapatkan bahwa masyarakat meremehkan masalah kesehatan terkait dengan tenggelam [4]. Salah satu pencegahan yang penting dilakukan untuk meminimalisir resiko tenggelam adalah melakukan pencegahan, yaitu dengan memberikan pemahaman akan faktor resiko dan memberikan edukasi akan penyelamatan dan bantuan hidup dasar [5]. Bantuan Hidup Dasar (BHD) merupakan tindakan untuk mempertahankan jalan nafas dan membantu pernafasan dan sirkulasi tanpa menggunakan alat selain alat bantu nafas sederhana. Kombinasi nafas bantuan dan kompresi dada disebut resusitasi jantung paru (RJP) [6].

Ketidakmampuan dalam menangani pasien gawat darurat umumnya disebabkan oleh kegagalan mengenal risiko, keterlambatan rujukan, kurangnya sarana yang memadai dan pengetahuan dan keterampilan masyarakat dalam mengenal keadaan risiko tinggi secara dini yang harus dilakukan secara efektif dan efisien [7]. Kesalahan atau ketidaktepatan pemberian pertolongan pertama pre hospital dalam melakukan pertolongan dapat menyebabkan kecacatan atau kematian penderita gawat darurat. Upaya yang harus dilakukan untuk meminimalkan angka kematian penderita gawat darurat harus mempersingkat response time [8].

Peningkatan pengetahuan masyarakat dalam upaya pemberian pertolongan pertama prehospital perlu dilakukan. Masyarakat yang tidak paham tentang pemberian pertolongan pertama akan cenderung memberikan pertolongan seadanya tanpa memikirkan tindakan yang dilakukan itu tepat atau tidak [9]. Selain itu, masyarakat awam biasanya hanya menunggu tim penolong datang tanpa memikirkan bagaimana kondisi korban yang akan ditolong padahal masyarakat awam dikatakan sebagai penolong pertama dan utama [10].

Sosialisasi dan simulasi merupakan upaya yang penting dilakukan untuk meningkatkan pengetahuan dan keterampilan masyarakat awam dalam memberikan pertolongan prehospital [11]. Sosialisasi dan simulasi ini baik diberikan sejak usia muda untuk menciptakan generasi muda yang berkompeten dalam mengaplikasikan serta mensosialisasikan cara untuk memberikan pertolongan prehospital [12]. Demi meningkatkan pengetahuan dan keterampilan masyarakat awam di Kawasan pesisir untuk memberikan pertolongan BHD yang tepat, maka berdasarkan analisis tim pengabdi di Desa Kawa Kabupaten Seram Bagian Barat untuk diberikan solusi yaitu melakukan Sosialisasi dan Simulasi BHD untuk masyarakat awam dengan sasaran adalah masyarakat yang berprofesi sebagai nelayan. Kegiatan ini dilakukan dengan metode tatap muka untuk berinteraksi secara langsung dengan memperhatikan protokol kesehatan.

\section{METODE}

Kegiatan ini dilaksanakan pada tanggal 02 Juli 2021 bertempat di Balai Desa Kawa Kabupaten Seram Bagian Barat. Metode yang digunakan dalam program pengabdian masyarakat 
ini adalah berupa penyuluhan atau sosialisasi (ceramah) dan demonstrasi (simulasi). Media yang digunakan yaitu power point, LCD, dan speaker.

Monitoring dan evaluasi diperoleh dari lembar presensi atau kehadiran peserta serta kemampuan nelayan untuk mengikuti sosialisasi dan simulasi. Kegiatan monitoring dilakukan dengan observasi langsung pada saat sosialisasi dan simulasi dengan melihat interaksi antara peserta dengan pemateri simulasi dan keaktifan nelayan dalam acara simulasi atau domonstrasi tindakan BHD. Evaluasi dilakukan dengan menilai peningkatan pengetahuan / simulasi tindakan BHD melalui evaluasi post test terakit materi dan demonstrasi yang dilakukan.

\section{HASIL DAN PEMBAHASAN}

Peserta pengabdian masyarakat ini adalah Nelayan Tradisional Desa Kawa yang dihadiri oleh 52 orang. Hasil kegiatan penyuluhan tentang pemberian Bantuan Hidup Dasar (BHD) pada nelayan tradisional dengan cara simulasi dan demonstrasi didapatkan yaitu setelah melakukan penyuluhan pengetahuan adalah cukup yaitu sebanyak 32 orang atau $(61,5 \%)$.

Tabel 1. Distribusi Frekuensi Tingkat Pengetahuan Nelayan Tradisional Sosialisasi dan Simulasi tentang Pemberian Bantuan Hidup Dasar pada Nelayan Tradisional di Desa Kawa Kabupaten Seram Bagian Barat

\begin{tabular}{lcc}
\hline \multicolumn{1}{c}{ Tingkat Pengetahuan } & F & Post Test \\
\hline Baik & 32 & $\mathbf{\%}$ \\
Cukup & 20 & 61,5 \\
Total & $\mathbf{5 2}$ & 38,5 \\
\hline
\end{tabular}

Pelaksanaan program pengabdian di Desa Kawa Kabupaten Seram Bagian Barat dilaksanakan pada hari Jum'at tanggal 02 Juli 2021 berjalan dengan baik dan lancar. Pengabdian ini ditujukan kepada masyarakat yang bermata pencaharian sebagai nelayan tradisional. Pendidikan para peserta hampir seluruhnya tamatan SD.

Program pengabdian berupa sosialisasi mengenai pemberian Bantuan Hidup Dasar pada masyarakat awam pada tahap pelaksanaan digunakan dua metode atau tehnik yaitu metode ceramah dan demonstrasi langsung.

Materi-materi yang disampaikan ternyata dapat meningkatkan pengetahuan mereka dibuktikan dengan respon yang cepat dalam menjawab semua pertanyaan yang diberikan dengan benar serta dapat langsung mempraktekkan bagaimana cara melakukan pemberian Bantuan Hidup Dasar. Sebagai tolak ukur peningkatan pengetahuan masyarakat adalah mereka dapat mempraktekkan kembali cara pemberian Bantuan Hidup Dasar bagi masyarakat awam serta mereka paham bahwa sangat penting pengetahuan pertolongan pertama tentang pemberian Bantuan Hidup Dasar jika ada teman kerja yang mengalami henti nafas dan henti jantung. Selain itu, peserta bisa mempraktekkan langsung langkah-langkah pemberian Bantuan Hidup Dasar setelah peserta dipandu oleh mahasiswa.

Berdasarkan evaluasi pelaksanaan kegiatan, dapat di identifikasi faktor pendukung dan penghambat dari kegiatan ini sehingga dapat berjalan dengan baik dan lancar antara lain dapat dukungan dari Kepala Desa dan Ketua Nelayan yang bersedia diajak bekerja sama dan mendukung program pengabdian masyarakat. Serta antusisme dari nelayan tradisional sebagai peserta dalam pengabdian masyarakat ini. Sedangkan faktor penghambat dalam pengabdian ini adalah saat pelaksanaan pengabdian masyarakat pada masa pandemi Covid-19 sehingga tetap mematuhi protokol kesehatan.

Berikut terdapat beberapa foto yang berhasil didokumentasikan pada saat kegiatan berlangsung:

a. Penerapan protokol kesehatan pada peserta 


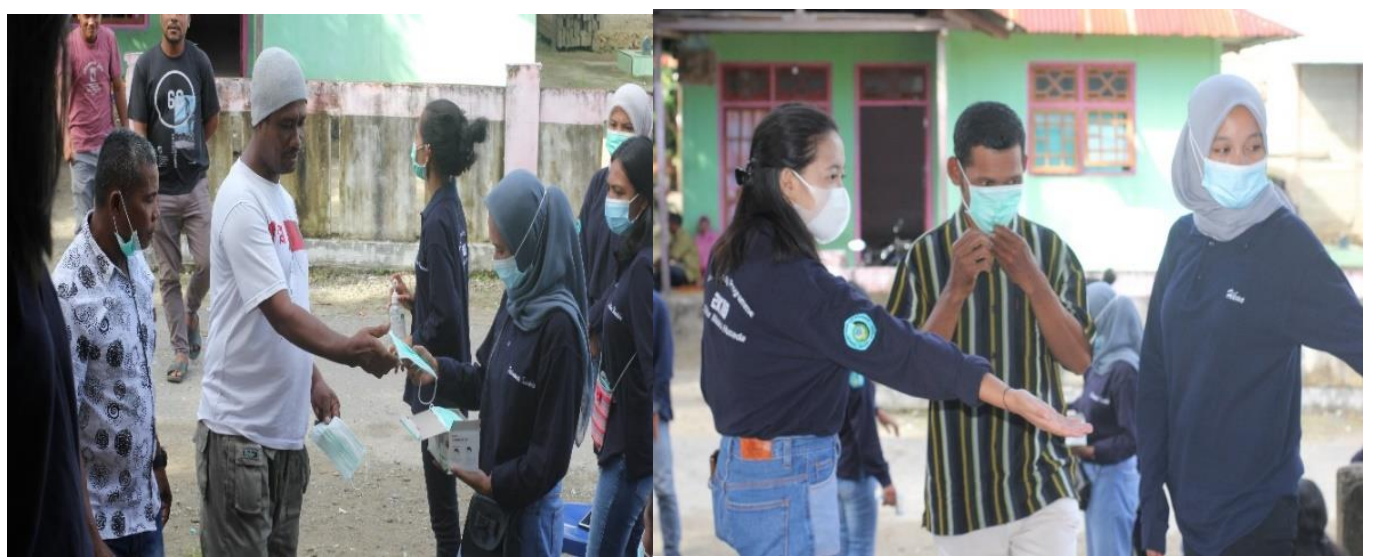

(a)

(b)

Gambar 1. (a) dan (b) Penerapan protokol kesehatan pada peserta

b. Sosialisasi Pemberian Bantuan Hidup dasar

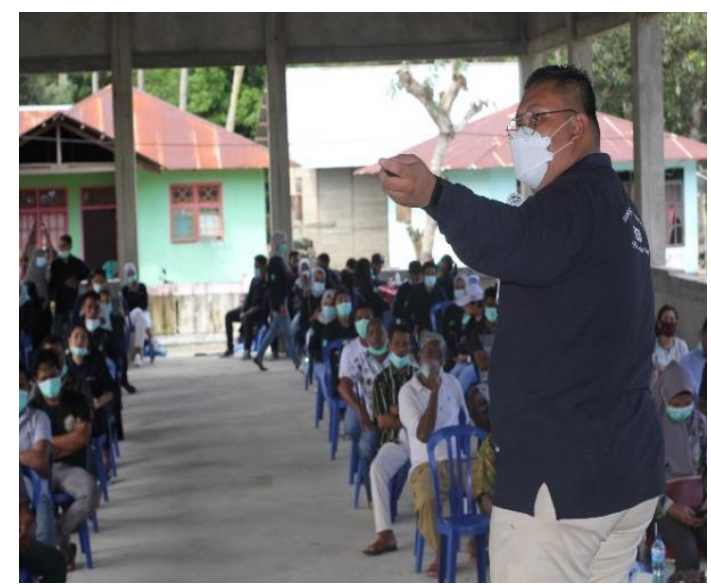

(a)

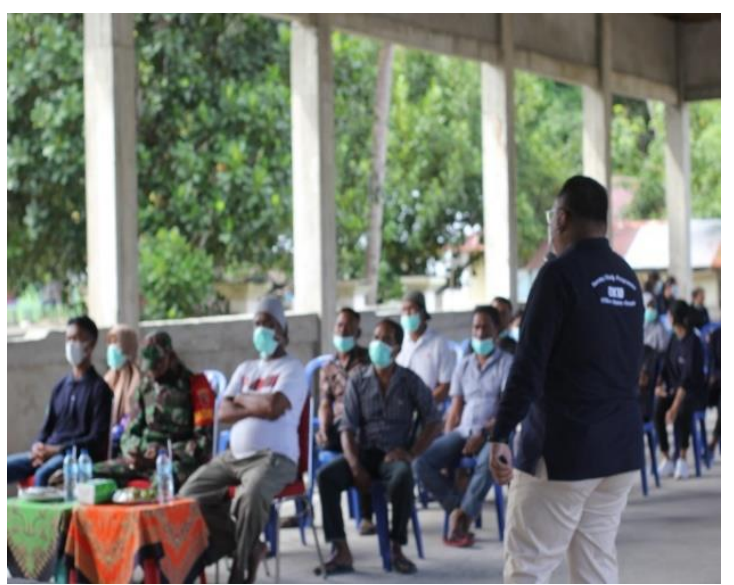

(b)

Gambar 2. (a) dan (b) Sosialisasi Pemberian Bantuan Hidup Dasar

c. Simulasi Pemberian Bantuan Hidup Dasar

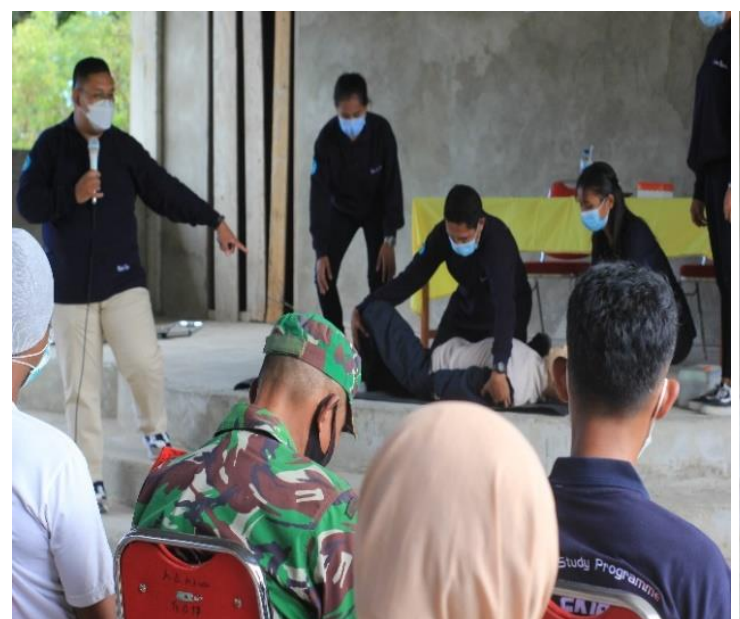

(b)

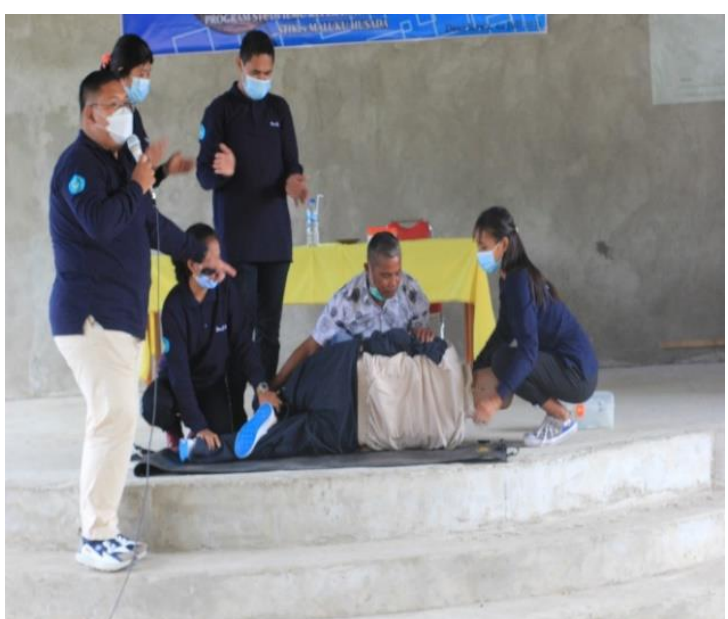

(b)

Gambar 3. (a) dan (b) Simulasi Pemberian Bantuan Hidup Dasar 


\section{KESIMPULAN}

Setelah mendapatkan sosialisasi dan simulasi pemberian Bantuan Hidup Dasar pada nelayan tradisional Desa Kawa Kabupaten Seram Bagian Barat terjadi peningkatan pengetahuan tentang pemberian Bantuan Hidup Dasar dan tahu bagaimana cara melakukannya. Peningkatan pengetahuan diketahui dari hasil post-test. Kenaikan nilai post-test sebesar $61,5 \%$ nelayan tradisional mempunyai pengetahuan baik dalam sosialiasi dan simulasi pemberian Bantuan Hidup Dasar.

\section{DAFTAR PUSTAKA}

[1] Kementerian Kelautan dan Perikanan, "Rencana Strategis Kementerian Keluatan dan Perikanan Tahun 2020-2024," Kementeri. Kelaut. dan Perikan., p. 19680407, 2020.

[2] K. Kusnanto, L. R. Wabula, B. Purwanto, H. Arifin, and Y. Kurniawati, "Safety behaviour and healthy diving: A qualitative study in the traditional diverse fishermen," Int. Marit. Health, vol. 71, no. 1, pp. 56-61, 2020, doi: 10.5603/IMH.2020.0012.

[3] L. R. Wabula, Perilaku Keselamatan dan Kesehatan Penyelaman pada Penyelam Tradisional Berbasis Health Action Process Aprroach, I., vol. 11, no. 2. Bandung: CV. Cakra, 20020.

[4] N. R. Paramata, I. Wulansari, I. S. Basir, and N. K. Rahim, Penerapan Basic Life Support Pada Masyarakat Dalam Menghadapi Bencana. 2018.

[5] Zurimi Suardi at al, "Peningkatan Pengetahuan dan Keterampilan melalui Penyuluhan dan Simulasi Bantuan Hidup Dasar pada Masyarakat Awam Pesisir di Dusun Kasuari Desa Asilulu Kecamatan Leihitu Kabupaten Maluku Tengah," PengabdianMu J. Ilm. Pengabdi. Kpd. Masy., vol. 5, no. 3, pp. 264-269, 2020.

[6] AHA, "Guideline Resusitasi AMERICAN HEART ASSOCIATION Tahun 2020," Am. Hear. Assoc., 2020.

[7] H. Syapitri et al., "Simulasi Bantuan Hidup Dasar (BHD) Di SMK Kesehatan Sentra Medika Medan Johor," Communnity Dev. J., vol. 1, no. 3, pp. 218-222, 2020, [Online]. Available: https://journal.universitaspahlawan.ac.id/index.php/cdj/article/view/918.

[8] I. M. Syahri and M. Fitria, "Keselamatan Dan Kesehatan Kerja ( K3 ) Pada Nelayan Di Pos Upaya Kesehatan Kerja ( Pos Ukk ) Puskesmas Belawan TALENTA Conference Series Keselamatan Dan Kesehatan Kerja ( K3 ) Pada Nelayan Di Pos," Talent. Conf. Ser. Trop. Med., vol. 1, no. 1, pp. 202-206, 2018.

[9] F. Purwangka, S. H. Wisudo, B. H. Iskandar, and J. Haluan, "Model Pengelolaan Keselamatan Kerja Nelayan Di Palabuhanratu, Kabupaten Sukabumi," J. IPTEKS Pemanfaat. Sumberd. Perikan., vol. 5, no. 9, pp. 1-18, 2019, doi: 10.20956/jipsp.v5i9.4312.

[10] G. I. V. Watung, "Edukasi Pengetahun dan Pelatihan Bantuan Hidup Dasar Pada Siswa Remaja SMA Negeri 3 Kotamobagu," Community Engagem. Emerg. J., vol. 2(1), no. Fajarwaty 2012, pp. 21-27, 2020.

[11] D. P. A. Yatma, "Efektivitas Metode Penyuluhan Audiovisual Dan Praktik Terhadap Tingkat Pengetahuan Bantuan Hidup Dasar Pada Nelayan Di Pantai Depok Yogyakarta," STIKes 'Aisyiyah Yogyakarta, pp. 1-11, 2015.

[12] C. J. Surudani et al., "IbM Bantuan Hidup Dasar di SMAN 1 Tahuna, Kabupaten Kepulauan Sangihe, Sulawesi Utara," E-Journal.Polnustar.Ac.Id, vol. 1, pp. 1-3, 2017, [Online]. Available: http://bareskrim.com. 